\title{
The Impact of Syrian Migration on Unemployment: Evidence from Turkey
}

\author{
Fatma Özgü SERTTAŞ* \\ Ankara Yıldırım Beyazıt University \\ Davut ULUÖZ** \\ Ankara Yıldırım Beyazıt University
}

\begin{abstract}
This study examines the labor market effects of the influx of the Syrian refugees in Turkey. Engle-Granger and Johansen co-integration tests, followed by the autoregressive distributive lag (ARDL) bounds tests reveal that the Turkish unemployment and Syrian refugee series are co-integrated; pointing out to a long-run relationship. Shortrun and long-run dynamics have been analyzed from the fitted ARDL model and the error-correction parameter is used to examine the speed of convergence. Dynamic OLS (DOLS), fully modified least squares (FM-OLS) and canonical co-integrating regression (CCR) estimations are used to make inferences about the co-integration parameters. Empirical results show that there is a significant and negative relationship between the level of unemployment in Turkey and the number of Syrian refugees in the long-run, indicating that the influx of Syrian refugees has had a reducing effect on unemployment numbers in Turkey. Our results suggest that the Syrian refugees have acted as a complementary labor force to the existing Turkish labor force.
\end{abstract}

\section{Keywords}

Forced Refugees, Migration, Unemployment, Co-integration, DOLS, FM-OLS, CCR, ARDL, Syrian Refugees

JEL Classification: F2, J6, H5

* Asst. Prof., Ankara Yıldırım Beyazıt University, Faculty of Political Sciences, Department of Economics, foserttas@yahoo.com, ORCID: 0000-0003-0746-3991.

** PhD Candidate, Ankara Yıldırım Beyazıt University, Faculty of Political Sciences, Department of Economics davutulu@gmail.com, ORCID: 0000-0001-6801-5856. 


\section{Suriyeli Göçmenlerin İşsizliğe Etkisi: Türkiye Kanıtı}

Öz

Bu çalışma, Suriyeli mülteci akınının Türkiye işgücü piyasası üzerindeki etkilerini incelemektedir. Engle-Granger ve Johansen eșbütünleşme testleri ve gecikmesi dağıtılmış otoregresif (ARDL) sınır testlerinin sonuçları, Türkiye'deki işsizlik serisi ve Suriyeli mülteci serisinin eşbütünleșik (ko-entegre) olduğunu, bu da iki serinin uzun vadeli bir ilişki içerisinde olduğunu ortaya koymaktadır. Kısa vadeli ve uzun vadeli dinamikler, ARDL model vasıtasıyla analiz edilmiş ve hata düzeltme parametresi denge yakınsama hızını incelemek için kullanılmıştır. Dinamik en küçük kareler (DOLS), tam değiştirilmiş en küçük kareler (FM-OLS) ve kanonik eşbütünleşme regresyonu (CCR) teknikleri eşbütünleşme parametre tahminlerinin çıkarımları için kullanılmıştır. Ampirik sonuçlara göre Türkiye'deki işsizlik düzeyi ile Suriyeli mülteci sayısı arasında uzun vadede anlamlı ve negatif bir ilișki olduğu görülmektedir. Bu negatif ilișki, Suriyeli mülteci akınının Türkiye'deki işsiz sayısını düşürmeye yönelik bir etki yarattığını göstermektedir. Sonuçlara göre, Suriyeli mülteci iş gücü ile mevcut Türkiye'deki iş gücünün birbirini tamamlayıcı güçler gibi davrandıkları söylenebilir.

\section{Anahtar Kelimeler}

Zorunlu Mülteciler, Göç, İssizlik, Eșbütünleșme, DOLS, FM-OLS, CCR, ARDL Sinır testi, Suriyeli Mülteciler 


\section{Introduction}

The Syrian civil war started in March 2011 and many Syrian refugees had to move to neighboring countries including Turkey. According to The United Nations High Commission of Refugees (UNCHR), 5,664,202. Syrians were displaced as of December 2019. Turkey followed open-door policy towards Syrians and started to accept Syrian refugees in April 2011. Since then there has been a massive influx of Syrian refugees into Turkey. As can be seen in Table 1 below, 3,691,333 Syrians - which corresponds to $65.2 \%$ of the Syrian refugees-, migrated to Turkey.

Table 1. Total registered Syrian refugees by country

\begin{tabular}{|l|c|c|c|}
\hline Host Country & Data date & Ratio & Refugee Population \\
\hline Turkey & 27 Nov 2019 & $65.2 \%$ & $3,691,333$ \\
\hline Lebanon & 31 Oct 2019 & $16.2 \%$ & 918,974 \\
\hline Jordan & 1 Dec 2019 & $11.5 \%$ & 654,192 \\
\hline Iraq & 31 Oct 2019 & $4.1 \%$ & 234,831 \\
\hline Egypt & 31 Oct 2019 & $2.3 \%$ & 129,159 \\
\hline Other (North Africa) & 30 Nov 2018 & $0.6 \%$ & 35,713 \\
\hline
\end{tabular}

Source: Syria regional refugee response: Total persons of concern, 2019.

Although Syrian refugees at first settled in refugee accommodation camps near the Turkey-Syria border in cities like Gaziantep, Şanlıurfa, Hatay, and Kilis, they started to move to the rest of Turkey quickly. Today, Syrians settled in almost every city in Turkey.

Initially, the Turkish government issued "temporary protection" for the Syrian migrants (Kirişçi, 2014). Later on, however, the enactment of law no. 8375 on January 11 of 2016 enabled the refugees to join the formal labor market in Turkey by providing legal work permits with certain conditions and workplace quotas.

Throughout history, Turkey has experienced refugee influx from different regions. The data about the biggest refugee inflows to Turkey after the year 1923 is given in Table 2. Unlike Syrians, none of the refugee numbers, however, reached a million. 
Table 2. Major refugee flows to Turkey after 1923

\begin{tabular}{|l|c|c|}
\hline Year & Refugee flows & Number of Refugees \\
\hline $1923-1950$ & Bulgaria, Greece, Yugoslavia, Romania & 850 thousand \\
\hline $1950-1970$ & Bulgaria, Greece, Yugoslavia, Romania & 372 thousand \\
\hline $1971-1986$ & Bulgaria, Yugoslavia, Afghanistan & 127 thousand \\
\hline 1988 & Iran, Iraq & 51 thousand \\
\hline 1989 & Bulgaria & 300 thousand \\
\hline 1991 & Iraq & 460 thousand \\
\hline $1992-1995$ & Bosnia-Herzegovina & 25 thousand \\
\hline $2011-$ Present & Syria & 3.6 million \\
\hline
\end{tabular}

Source: Bahçekapılı and Çetin (2015: Table 2)

The number of Syrian refugees has reached 3.6 million in December 2019, which is equivalent to $4.2 \%$ of the Turkish population. As the intensity and duration of the civil war increased, the concerns of people in Turkey increased as well. Turkish citizens and policy makers have been mainly concerned about the Syrian refugees' social, political, economic and even demographic impacts on Turkey. The impact of migrants on the labor market opportunities of Turkish workers in particular has been discussed widely among policymakers and scholars.

As Figure 1 shows, just before the Syrian conflict in 2011, the unemployment rate in Turkey was about $8.2 \%$ (September of 2011). It then decreased to $7.3 \%$ in June 2012. In January 2019 , it reached $14.7 \%$, since then however, it has been fluctuating around $14 \%$.

In this study, we explore the impacts of Syrian refugees on the Turkish labor market in a time series context, trying to shed some light on the ongoing debate about Syrians and how they affect the Turkish economy. We analyze the system dynamics of the monthly series of the number of Syrian refugees and the monthly unemployment series in Turkey for the period 2011:11 2020:02. We find that the unemployment data and refugee data are co-integrated in Turkey both through residual-based tests (Engle and Granger, 1987) and likelihood-ratio type tests (Johansen, 1988, 1991). ARDL bounds tests (which perform quite well for small sample sizes such as ours) confirm the long-run co-integration result. This points out there exists a significant long-run relationship between the number of unemployed persons in Turkey and the number of Syrian migrants to Turkey and the trends of our variables are linked (Engle and Granger, 1987). Co-integration implies that the series share common stochastic trends and there exists a long-run equilibrium path. If there is any disequilibrium occurring in the short-run, at least one of the variables must respond to return to this long-run path. Analyses show a 
unidirectional causal relation, running from Syrian refugee series to unemployment series in Turkey but not vice versa. Short-run and long-run coefficients have been analyzed from the fitted ARDL model and the error-correction parameter is used to quantify the speed of convergence. Fully-Modified OLS (FM-OLS), canonical co-integrating regression (CCR), dynamic OLS (DOLS) models are used to quantify the direct long-run impact of Syrian refugee series on unemployment. Our results suggest that, Syrian refugees have played a significant role in reducing the level of unemployment in Turkey on an aggregate level and Syrian refugees have acted as a complementary labor force to the existing Turkish labor force.

Figure 1. Unemployment rate in Turkey (in percentages).

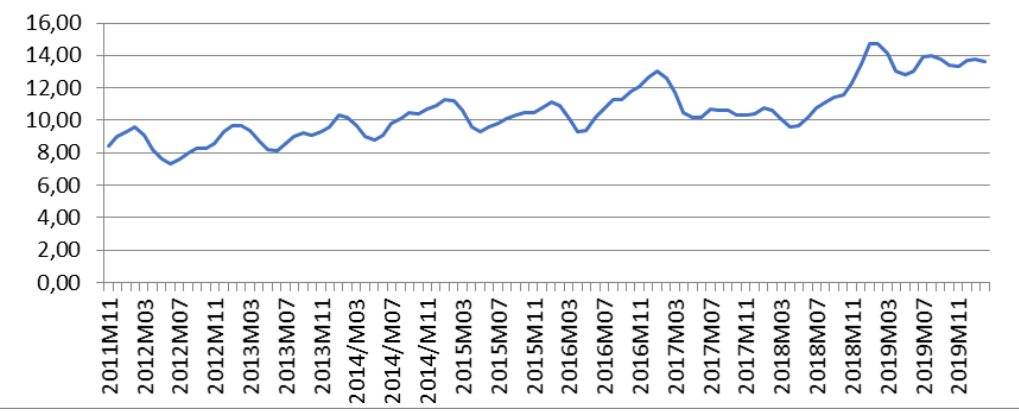

\section{Theoretical background}

In this section, we discuss the possible labor market impacts of Syrian migration on the domestic (Turkish) labor market (Borjas, 2013: 164-178). Figure 2, Figure 3 and Figure 4, display labor demand - labor supply analyses on refugee influx where the incoming refugees act as substitutes or complements. Based on these discussions, we thrive to investigate the answers of questions such as: "If the influx of Syrian refugees acts as a labor supply shock to the Turkish labor market, how will the Turkish labor market react and adjust after this shock?" "Will the refugees lower the job opportunities of Turkish workers?" "Will they take jobs away from Turkish workers or help to create jobs for the natives?"

The discussion in Borjas (2013) is centered around the sizeable supply shifts that occurred in the US economy due to large-scale immigration, and the questions about the short-run and long-run effects of these labor supply shocks. Theoretically, if the immigrants are perfect substitutes for the existing labor force in the production process, the immigrants will compete with local workers on the same types of jobs with same types of skills which will lower wages. Figure 2 shows the short-run employment effects of refugees 
when refugees are perfect substitutes for local workers. As Figure 2 depicts, in the short-run (when capital is fixed), the influx of immigrants shifts the labor supply curve to the right, and equilibrium wages decline. Although total employment increases, native employment decreases because fewer native workers are willing to accept lower wages. So, the unemployment among the local labor force increases and wages decline due to increased competition.

Figure 2. Short-run effects: Case of perfect substitutes

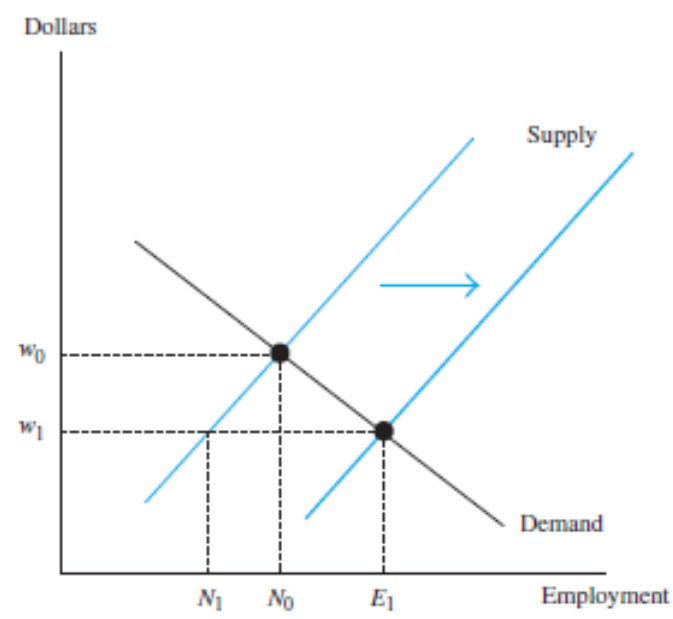

Source: Borjas (2013: Figure 4-10)

On the other hand, immigrants may be particularly good at some types of labor-intensive agricultural production, which might force the more skilled native workforce to go for highly qualified jobs, increasing the domestic workforce's productivity. This happens when the two workforces are complements. Dumont and Liebig (2014) argue in OECD 2014 migration policy debates that, migrants can bring new skills and human capital to the host country and can fill important niches both in fast-growing and declining sectors of the economy. If the skill mix of Syrian refugees is different from the Turkish workers, they will not compete in the same labor market with the Turkish workers, not for the same type of jobs. If the Syrian migrants and Turkish natives are complements, Syrian refugees can push the Turkish workers to specialize in tasks that are better suited to their job skills and marginal productivities of Turkish workers increase. Figure 3 shows the short-run employment effects of refugees when refugees are complements for local workers. As can be seen from Figure 3, native workers' labor demand curve shifts to the right; the equilibrium wages and employment opportunities of Turkish workers will be higher. There is also an additional incentive to enter the labor market among the natives. 
Figure 3. Short-run effects: Case of complements

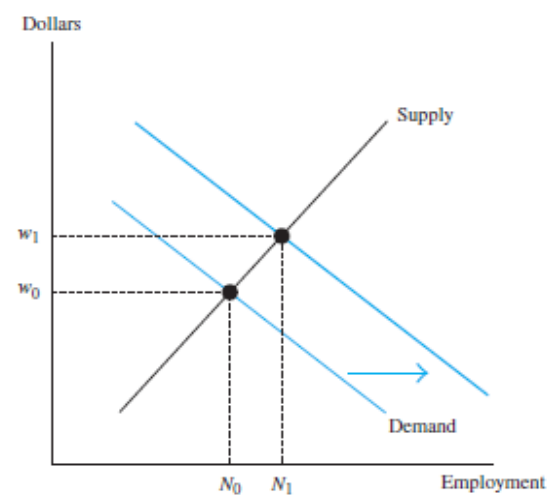

Source: Borjas (2013: Figure 4-11)

In the long-run when capital flows are free, the flows are expected to adjust the wage rates. Long-run adjustment process in the labor market for perfect substitute case is given in Figure 4. In the figure, the economy adjusts completely at the same rate of return to capital and the same wage rate as the demand curve shifts right while there is an expansion of existing firms and entering new firms. At this point, how much the demand curve will shift is crucial and depends on country-specific factors.

Figure 4. Long-run effects: Case of perfect substitutes

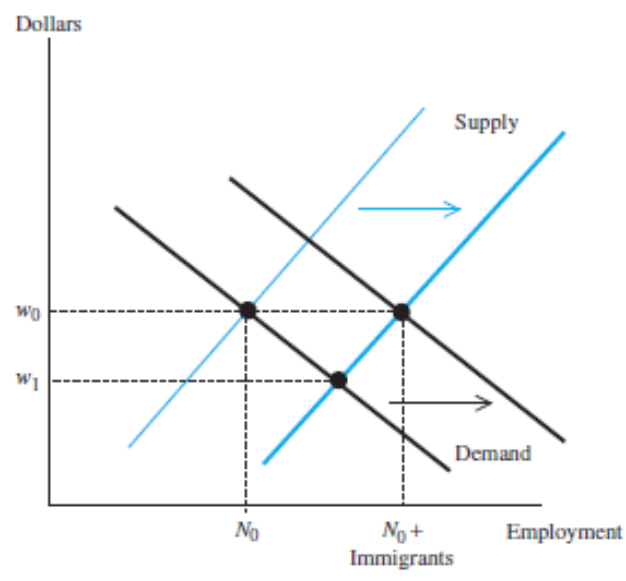

Source Borjas: (2013: Figure 4-12)

The long-run scenario of Figure 4 seems to be in line with the findings of Docquier et al (2011), who study the labor market effects of immigration and 
emigration in OECD countries for the years 1990 and 2000. They find that migrants entering a host economy either increase or do not affect the average wages or employment opportunities of native workers. ${ }^{1}$

Determining whether the migrant workers and natives are complements or substitutes is important. In the sectors where they are substitutes, the economic opportunities of native workers can be altered negatively, with lower wages and employment. If they are complements, however, native earnings and employment opportunities can be better; with refugees filling gaps and making native workers shift to more productive jobs. In reality, the two workforces might not be entirely substitutes or complements; in some sectors they might act as substitutes while in others they might act as complements. In this paper, we consider aggregate data and try to analyze the big picture: the overall impact of refugees.

\section{Related literature and contribution}

Mariel boatlift in the 1980s is one of the earliest examples of mass foreign migration. The unemployment impacts of the Mariel boatlift are explored in Card (1990). Thousands of Cubans moved from Cuba's Mariel Harbor to the United States, increasing the Miami labor force by 7\%. Card (1990) reports in his research that there is virtually no effect of this migration on the wages or unemployment rates of less-skilled workers in the US. Card explains this result by the high absorption capacity of the Miami labor market, although, Rapael et al. (2007) explains it by capital accumulation and imperfect substitutability. Hunt (1992) investigates the effects of the migration of 900,000 repatriates (migrants who came from Algeria to mainland France in 1962), representing the $1.6 \%$ of the total French labor market and finds that unemployment has increased among non-repatriates by at most 0.3\% in 1968.

Cohen-Goldner and Paserman (2004) study the massive migration from the former Soviet Union to Israel in the 1990s (representing an 18\% increase in Israel's population) through a skill-level approach. They find a significant but temporary effect on wages but no effect on employment. Hercowitz and Yashiv (2002) study the same migration with an open-economy macroeconomic model using a differential entry of immigrants into the labor and goods markets. They reach a conclusion that immigrants lead to delayed and temporary unemployment among natives.

Although all the cases mentioned above are important to the local economies, the number of refugees dealt with is not as large as the influx of the migrants caused by the Syrian civil war in 2011. In Syrian case, 5,664,202 people have been displaced as of December 2019. As mentioned above, Syrian refugees had moved to neighboring countries like Turkey, Lebanon, Jordan and Iraq,

1 This scenario is possible when the aggregate production function has constant returns to scale. 
creating an interest to investigate the impacts of this massive migration on host economies.

Ali and Ibrahim (2016) investigate the economic impact of Syrian refugees in Jordan, one of the major refugee-accepting countries like Turkey. They make use of the UN Refugee Agency (UNHCR)'s monthly data between January 2012 and December 2013 and implement a VAR methodology. They conclude that there is no significant relationship between the influx of Syrian refugees and the Jordanian labor market. ${ }^{2}$ They propose that this might be due to the additional measures taken by the government to prohibit hiring Syrian refugees. Fallah et al. (2019) analyze the effect of Syrian refugees on Jordanian economy as well by using various models (panel and difference-in-difference) using yearly data from 2010 to 2016 . They report no adverse labor market outcomes for Jordanians living in the areas with a high level of concentration of refugees. David et al. (2020) study the economic and social impacts of the Syrian war on Lebanon with a general equilibrium approach and conclude that the impact of influx of Syrian refugees depends on the skill composition of natives; although immigrants have positive impacts on high-skilled natives, they have negative impacts on medium or less-skilled natives.

Some works in literature find little or no effect, some find negative effects of Syrian refugees on native labor markets. The labor market conditions and country-specific factors such as product markets, labor market policy settings and the quality of migrant workers, and different migration policies in different countries may lead to different outcomes. Specific analysis for Turkish experiment is needed of course, to determine the labor market impact of Syrian refugees in Turkey. Below, we provide some of the studies that have been carried out for the Turkish case.

Akgündüz et al. (2015) analyze the effect of Syrian refugees on food and housing prices, employment rates and internal migration patterns in Turkey. They use aggregate labor market data for the years 2012 and 2013 with region-time variation. Since refugee camps are concentrated in south eastern regions, they take the rest of Turkey as control group and use difference-in-difference method to analyze local impacts. They conclude that while housing and food prices are increasing, employment rates in skill groups are largely unaffected. Bahçekapılı and Çetin (2015) study the economic impact of Syrians using TURKSTAT data on workforce, prices, internal migration and foreign trade in southeastern Anatolia. They use cross section differencing method with pre- and post-migration data. They find that internal migration has increased and foreign trade balance has improved in all of the seven regions examined after Syrian refugees have arrived. Syrian refugees lead to an increase

2 In this study, we show that our macroeconomic unemployment series and refugee data are co-integrated. Thus, in our case it is not appropriate for us to difference the data and opt for a VAR analysis, this will leave out the error correction portion of variables and misspecify the model (Enders, 2015: p. 358). 
in unemployment in certain regionsexcept for TRC1 Region (Gaziantep, Adlyaman and Kilis or GAK), which hosts the densest Syrian refugee population. This region has experienced the highest foreign trade recovery and maximum inflation compared to other regions.

Del Carpio and Wagner (2015) investigate the effect of Syrian refugees on the Turkish labor market in 26 NUTS2 regions, using the 2011-2015 data obtained from Turkish Household Labor Force Survey, Disaster and Emergency Management Presidency of Turkey (AFAD) and Ministry of Interior. By employing difference in difference method and distance-based instrumental variable (IV) approach with an instrument of weighted distance to Syrian border. While Syrian refugees displace local workers in informal, part time jobs especially in agriculture, they also induce formal higher wage jobs and regular employment in Turkey. Syrian workers displace natives in the informal jobs and low educated female workers' jobs especially in agricultural sector. Aksu et al. (2018) replicate the study by relaxing the common-trend assumption across regions and allowing for region-specific time trends. They analyze the data of TURKSTAT's Turkish Household Labor Force Surveys between 2004 and 2015 using a difference-in-differences, OLS, 2SLS and instrumental variable IV model. Their findings suggest no adverse effects on the average wages and total employment except for women. However, the type of male employment changes from wage employment to self and unpaid employment. Total employment of women, on the other hand, falls because women who lose their part time jobs leave the labor market. There are favorable effects on the employment in the formal sector. Both wage and employment of men in the formal sector increase. Wages of women in the full-time formal employment increase as well. They find substantial adverse effects of Syrians on the employment of men in informal sector, of women in all sectors. They find oneto-one replacement of native male worker in the informal sector. Although employment and wages of natives in the construction and agriculture sectors are adversely affected, native employment and wages are positively affected in the manufacturing and services sectors.

Akgündüz and Torun (2019) study the impact of low skilled Syrian refugees on the complexity of tasks performed by Turkish workers and capital intensity of firms in Turkey using Turkish Household Labor Force Survey and administrative data provided by firms to Revenue Administration for tax purposes in Turkey. They take 2014 and 2015 as treatment years and 2010 and 2011 as control years. Following Del Carpio and Wagner (2015), they use the same distance-based instrument to account for the causal effect of Syrian refuges and Two-Stage Least Squares (2SLS) regression analysis. They conclude that Syrian refugues increase the complexity of the jobs performed by local workers, pushing locals from manual jobs to more abstract and complex jobs, which suggests that Syrian refugees are substitutes in jobs requiring manual tasks. 
ORSAM's 2015 report by Orhan and Gündoğar, conduct field studies in the provinces of Adana, Osmaniye, Hatay, Kilis, Gaziantep, Sanliurfa, Mersin and Kahramanmaras, and conclude that Syrian refugees' have some significant contributions to the local economies and to the economy on national level in a good sense. They report that there has been an increase in rental house prices and living costs (for basic food products) due to higher demand. Although there are complaints about Syrians being employed illegally as cheap labor and taking away native jobs in some industrial, agricultural and small business jobs, Syrians do fill the gap by working as unskilled labor in the jobs that Turkish workers do not want to take part in. Moreover, they report a significant increase in commercial activity of Syrians through networks and relationships with the Middle East. Those investment activities by Syrian migrants especially in the manufacturing sector flourish the economic conditions where the refugees reside.

Ceritoğlu et al. (2017) study the effects of Syrian refugees on Turkish labor market by comparing the before and aftermath of Syrian migration, using a difference-in-differences approach and a micro level data set between 2010 and 2013 obtained from TURKSTAT Labor Force Surveys. They define the treatment group as 5 regions with refugee/population ratio above $2 \%$ and control group as 4 regions with refugee/population ratios close to 0 . They conclude that formal employment increases slightly; employment of Turkish workers - informal workers particularly has been considerably affected.

Tümen (2016) studies the impacts of Syrian refuge inflow on labor markets, consumer prices, and housing rents in Turkey. He adopts the method of quasi-experimental regional variation of refugee concentration and uses a difference-in-differences approach with TURKSTAT Labor Force Survey (LFS) micro-level dataset, treating $2010-2011$ as the pre-immigration period and 2012-2013 as the post-immigration period. He reports that informal employment of local workers is decreased by $2.26 \%$ while formal employment of local workers is increased by $0.46 \%$. Overall, Syrian refugees increase unemployment to population ratio by $0.77 \%$ while labor force participation is decreased by $1.03 \%$.

Esen and Binatlı (2017) use panel data for the years between 2004 and 2016 on 26 NUTS 2 (Nomenclature of territorial units for statistics-classification) regions in Turkey to investigate the impact of Syrian refugees on regional labor markets. They employ panel data for 26 regions for the years between 2004 and 2016. They conclude that Syrian refugees lead to an increase in unemployment and decrease in informal and formal employment. Çakıcı (2017) finds a similar result suggesting that Syrian refugees increase the level of unemployment, especially in the informal sectors of Turkey.

Cengiz and Tekgüç (2018) study the effect of migration on local economies between 2012 and 2015. They obtain data on Syrian guests from the Ministry 
of Interior Directory General of Migration Management database, data on new firm establishments published by The Union of Chambers and Commodity Exchanges of Turkey employment data from Household Labor Force Surveys, the official statistical institute of Turkey (TURKSTAT). They employ difference-in-differences method, generalized synthetic control (GSC) method to account for regional trends, OLS with regional treatment intensity variable, 2SLS model and canonical production function. They find no adverse effect on local's employment or wages opportunities. Moreover, the study finds that Syrian immigration boost regional demand, capital supply and productivity.

Suzuki et al. (2019) use micro-level data from TURKSTAT to study the labor market outcomes of Syrian refugees, using a difference-in-differences approach with 2010-2011 as the pre-treatment period and 2012-2015 as the post-treatment period. They take five regions with the highest refugees as treatment group and four comparable regions with a low refugee-to-population ratio as control group. They find negative employment impact in the bordering regions. This effect becomes larger in 2014-2015 compared with 2012-2013 years. Refugees displaced informal workers and females exit the labor market after the arrival Syrian refugees.

Existing studies have produced mixed results. Many studies on Turkey, have been carried out either on a micro level or regionally, dividing Turkey into subgroups. We intend to contribute to the existing works through analyzing the time-dynamic interactions between the Syrian migration data and Turkish unemployment data on an aggregate level by making use of officially announced numbers. Our aim is to provide a time series approach to Turkish macro-level data and analyze the short-run and long-run interactions between our series.

Our study is in line with existing literature which tries to capture the relationship between immigration and macroeconomic variables. For instance, Feridun (2007) investigates the relationship between immigration and GDP per capita and unemployment in Sweden by using autoregressive distributed lag (ARDL) bounds testing approach and Granger-causality tests using annual data between 1980 and 2004. It is somehow customary to use time aggregated data (annual data) to investigate the long-run relationships in immigration studies. ${ }^{3}$ However, in the light of the discussions and points made

3 Engin and Konuk (2020) use time aggregated annual data between 1995 and 2019 to investigate the effects of international immigration (not specifically Syrian immigration but total immigration) on Turkish unemployment and economic growth. Interestingly, they find that immigration positively affects the unemployment and economic growth both. A similar study by Meçik and Koyuncu (2020) analyse the causality between economic growth and total immigration in Turkey for annual data between 1991 and 2018. They find unidirectional causality from immigration to economic growth. 
in Haug (2002), we prefer to use high-frequency data with a larger sample size to implement the time series techniques in our study. 4

\section{Data and methodology}

\section{Data}

Monthly unemployment (UN hereafter) data are obtained the Central Bank of Turkey (TCMB, 2020). Syrian refugees (REF hereafter) data are from The United Nations High Commission of Refugees (UNCHR, 2020). The data cover the period from 2011:11 to 2020:02. Graphical representations of the data are given in Figures 5 and 6.

After reaching 14.8\% in 2009:02, Turkey had been experiencing a declining unemployment rate until the arrival of Syrian Refugees in 2011. Unemployment rate was 9.3\% when the first group of Syrians arrived in April 2011. But, unemployment rate seems to change its downward trend and started to increase over time. It reached $14.1 \%$ in July 2019. A visual inspection of the Unemployment series in Figure 5 shows that there is seasonal pattern with a trend. Therefore we work with seasonally adjusted data, and include a linear time trend in all our estimations.

Figure 5. The number of unemployed persons in Turkey

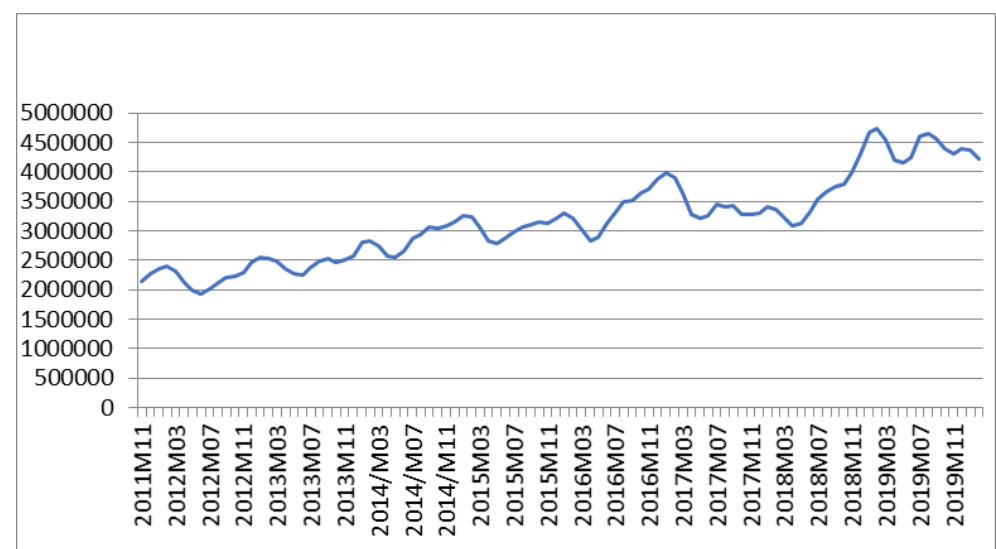

Source: Central Bank of Turkey (TCMB, 2020)

The first Syrian refugees began to cross into Turkey in March 2011. Turkey's open gate policy, since the beginning of the ongoing civil war, made it possible, for the number of Syrian refugees in Turkey to increase with an accelerating trend, as can be seen in Figure 6 below. But Syrian refugees living in

4 Haug (2000) shows cases when all tests' powers decline as the researcher converts data from monthly frequency to annual frequency (Haug, 2000: p. 407). Temporal aggregation is preferred in practice by researchers, however, there are many problems that arise when sample size is reduced. 
Turkey have been stabilized around about 3.6 million. A visual inspection of the series in Figure 6 shows that there is an upward trend.

Figure 6. The number of Syrian refugees in Turkey

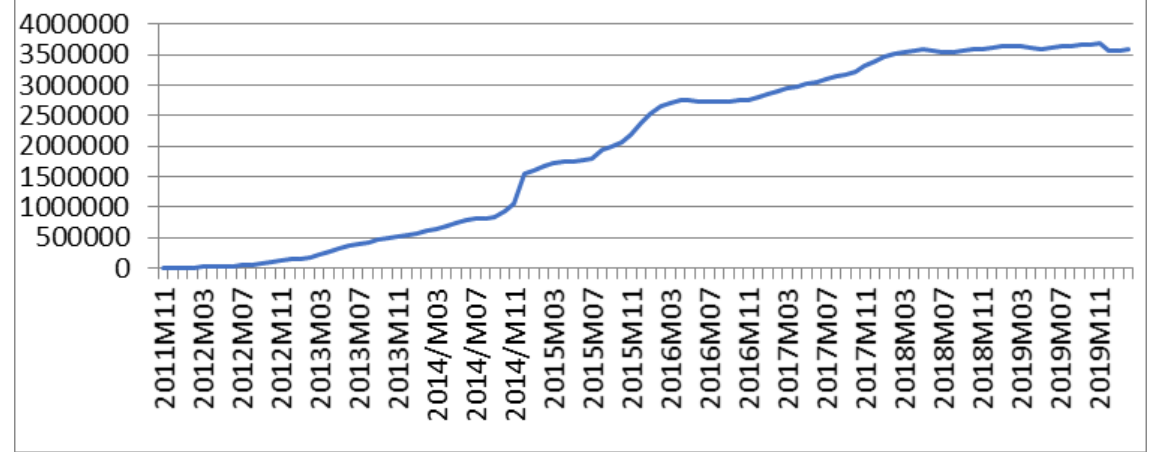

Source: The United Nations High Commission of Refugees (UNCHR, 2020).

\section{Methodology}

We check for co-integration between our time series and apply ARDL model estimations, followed by FM-OLS, DOLS and CCR estimations. We are dealing with long-run interactions, so we also test the direction of causality for our variables in Granger sense (Toda-Yamamoto test).

\section{Unit root tests}

We start by applying Dickey-Fuller (DF) $(1979,1981)$ test and Phillips-Perron (PP) (1988) test to check for the degree of integration of our data variables.

Dickey-Fuller (1979) test runs OLS and checks the stationarity in the following $\mathrm{AR}(1)$ process,

$$
\Delta \mathrm{y}_{\mathrm{t}}=\alpha+\beta \mathrm{y}_{\mathrm{t}-1}+\gamma \mathrm{t}+\mu_{\mathrm{t}}(1)
$$

We aim to test if $\beta=0$, so that we determine whether there is unit root in data. Alternative hypothesis is $\beta<0$, meaning the data is stationary. 5

Augmented Dickey-Fuller (1981) augments the Dickey-Fuller (1979) test by adding higher order lags of $y_{t}$ into the model to make error terms serially uncorrelated. Phillips and Perron (1988) test modify the Dickey Fuller test statistic for heterogeneity and autocorrelation in the error process, it allows the errors to be weakly dependent and heterogeneously distributed. We apply unit root tests with constant and trend in the equation.

5 In the text, we do not give all theoretical details about the econometric tests. The reader is referred to the cited papers for specific test details and the test statistics. 


$$
\mathrm{y}_{\mathrm{t}}=\alpha+\beta \mathrm{y}_{\mathrm{t}-1}+\gamma(\mathrm{t}-\mathrm{T} / 2)++\mu_{\mathrm{t}}(2)
$$

In Equation (2), T denotes the sample size of the time series. ${ }^{6}$

\section{Co-integration tests}

In order to check for a long-term relationship between UN and REF series, we have undertaken Engle and Granger $(1987)$ z-test and Johansen $(1988,1991)$ maximum eigenvalue and trace tests.

Engle-Granger (1987) tests the co-integration among variables by looking at the residuals of the long-run equilibrium of I(1) variables,

$$
\mathrm{y}_{\mathrm{t}}=\theta^{\prime} \mathrm{x}_{\mathrm{t}}+\mu_{\mathrm{t}}(3)
$$

$\theta$ is estimated by OLS and the residuals in this regression estimate the deviations from the long-run relationship. If the residual terms are stationary or $\mathrm{I}(0), \mathrm{y}$ and $\mathrm{x}$ series are co-integrated of order 1 denoted as $\mathrm{CI}(1,1)$.

Johansen $(1988,1991)$ test is a multivariate generalization of the Dickey-Fuller test. It enables to test for the presence of multiple co-integrating vectors (Enders, 2015).

$$
\Delta x_{t}=\pi x_{\mathrm{t}-1}+\mu_{\mathrm{t}}(4)
$$

Where $\pi=\left(A_{1}-I\right), A_{1}$ is nxn matrix, $I$ is nxn identity matrix.

Rank of $\pi$ gives the number of co-integrating vectors. Its characteristic roots are tested for co-integration with $\lambda_{\text {trace }}$ and $\lambda_{\max }$ test statistics.

\section{Autoregressive distributed lag (ARDL) model estimation}

ARDL is introduced by Pesaran and Shin (1999) and improved by Pesaran et al. (2001). ARDL model can be applied to times series data when the series are integrated of different order, purely stationary I( 0$)$, purely non-stationary I(1) or combination of the both or mutually co-integrated.7 The bounds test of a long-run relationship can be applied for relatively small sample sizes (see for example Narayan (2005)).

The following model is used for ARDL bounds test, to test the co-integration between our variables UN and REF. The model contains two time series variables, where each is expressed as a linear function of $p$ lags of itself and q lags of the other variables. The equation is as follows:

$$
\Delta(U N)_{t}=c_{0}+\sum_{i=1}^{p} c_{1 i} * \Delta(U N)_{t-i}+\sum_{i=1}^{q} c_{2 i} * \Delta(R E F)_{t-i}+c_{3} * U N_{t-1}+c_{4} * R E F_{t-1}+\mu_{t}(5)
$$

6 We denote the errors by $\mu_{\mathrm{t}}$ throughout the paper.

7 This feature of ARDL estimation is more useful to know if one has more than two time series variables. In our case, however, with two variables we still need to show that both our variables are I(1) in the search of a long-run equilibrium since the linear combination of two variables (if one is I(1) and the other is I(0)) will be trivially I(1), no need to test for a co-integrating relationship). 
The coefficient $c_{0}$ represents the intercept, $c_{1}$ and $c_{2}$ represent short-run coefficients, the coefficients $c_{3}$ and $c_{4}$ represent long-run coefficients, $\mu_{t}$ is the disturbance term. The null hypothesis that there is no co-integration is defined as;

$\mathrm{H}_{0}: \mathrm{c}_{3}=\mathrm{c}_{4}=0$ (no long-run relation between variables)

$\mathrm{H}_{1}$ : There exists long-run relation between variables

Above model is estimated by OLS method and then F-statistic is compared to its critical values. ${ }^{8}$ The null hypothesis is rejected when F-statistic is higher than the upper critical value: it means the variables are co-integrated and long-run relationship is confirmed.

In practice, we start by estimating the following form of ARDL ( $p, q)$ model: ${ }^{9}$

$$
(U N)_{t}=c_{0}+\sum_{i=1}^{p} c_{1 i}(U N)_{t-i}+\sum_{i=1}^{q} c_{2 i}(R E F)_{t-i}+\mu_{t}(6)
$$

ARDL model captures both short-run and long-run relationships among variables simultaneously. Short-term and long-term dynamics can also be examined by the error correction model (ECM). ECM model integrates short-run adjustments into the long-run equilibrium:

$\Delta(U N)_{t}=e_{1}+\sum_{i=1}^{p} e_{2 i} \Delta(U N)_{t-i}+\sum_{i=1}^{p} e_{3 i} \Delta(R E F)_{t-i}+e_{4} R E F_{t-1}+e_{5} U N_{t-1}+\mu_{t}(7)$

In Equation (7), $e_{5}$ is the speed of adjustment parameter and denotes the error correction term. The error correction term is estimated to find out how much correction is done in the short-run to revert back to the long-run equilibrium in case of any deviation occurring in the short-run.

\section{Fully modified OLS (FM-OLS), canonical co-integrating regression (CCR), and dynamic OLS (DOLS) estimations}

We use Phillips and Hansen (1990)'s FM-OLS, Park (1992)'s canonical co-integrating regression (CCR), and Stock and Watson's (1993) DOLS to further investigate the co-integrating relationship between the variables. Throughout the text, we try to use more than one technique and more than one estimator to signify our concern about the robustness of our results (see for example Narayan (2005)).

FM-OLS, CCR, and DOLS improve on the OLS estimator. Phillips and Hansen (1990) propose an unbiased and asymptotically efficient Fully Modified OLS (FM-OLS) estimator. FM-OLS corrects the endogeneity problem. Park (1992)'s

8 Since we are not dealing with stationary variables, F-statistic's distribution is no longer the F-distribution; the distribution derived by Pesaran et al. (2001). Small sample critical values are derived by Narayan (2005).

9 It is a typical starting point to estimate ARDL, this form is also called the intertemporal dynamics regression. This is the basis of the ARDL estimation, next we proceed with bounds testing and ECM model in an equivalent form. 
canonical co-integrating regression (CCR) method is similar to FM-OLS method, and makes use of stationary transformations of the data to remove the long-run dependence between the co-integrating equation and stochastic regressors innovations. Stock and Watson (1993)'s DOLS estimates dynamic long-run relationships using dynamic OLS. DOLS corrects for possible endogeneity, autocorrelation and small sample bias by including the lags and leads of the difference in the regressors (Al-Azzam and Hawdon, 1999). A general specification of DOLS model for our data is as follows:

$$
(U N)_{t}=a+b *(R E F)_{t}+\sum_{i=-j}^{j} b_{i} * \Delta(R E F)_{t-i}+\mu_{t}(8)
$$

where, $j$ is the leads and lags of the regressor (REF).

\section{Empirical results}

\section{Unit root tests}

Table 1 and Table 2 report the results of the unit root tests for the number of unemployed persons (UN) and the number of Syrian refugees in Turkey (REF). The results of the ADF test show both of UN and REF series have unit root and hence they are non-stationary at levels, while they are both stationary at first difference. The test has the null hypothesis of presence of a unit root. Furthermore, Philips-Perron (PP) test is utilized to double check the results. The results of PP test confirm the results of ADF test that both unemployment and refugees series are I(1) at 10\%, 5\% and 1\% significance levels. 10

10 We apply a series of different unit root tests as suggested by an anonymous referee. Lee and Strazicich (2003) test allows for two structural breaks in data. Although the results of those unit root tests are not reported here for conserving space, we confirm that the refugees and unemployment data are showing unit root properties also under the existence of structural breaks. In addition, the results of Ng and Perron (2001) unit root tests confirm the presence of a unit root in REF and UN series. All results are available from the authors upon request. 
Table 1: ADF test

\begin{tabular}{|c|c|c|c|}
\hline \multicolumn{4}{|c|}{$\underline{\text { At level }}$} \\
\hline & & UN & REF \\
\hline \multirow[t]{2}{*}{ With Constant } & t-Statistic & -1.1908 & -1.0079 \\
\hline & Prob. & 0.6761 & 0.7481 \\
\hline \multirow[t]{2}{*}{ With Constant \& Trend } & t-Statistic & -2.9647 & -0.6658 \\
\hline & Prob. & 0.1475 & 0.9724 \\
\hline \multirow[t]{2}{*}{ Without Constant \& Trend } & t-Statistic & 0.9720 & 1.8661 \\
\hline & Prob. & 0.9115 & 0.9848 \\
\hline \multicolumn{4}{|c|}{ At first difference } \\
\hline & & $\Delta(\mathrm{UN})$ & $\Delta$ (REF) \\
\hline \multirow[t]{2}{*}{ With Constant } & t-Statistic & -6.0163 & -6.3979 \\
\hline & Prob. & $0.0000^{* * *}$ & $0.0000^{* * *}$ \\
\hline \multirow[t]{2}{*}{ With Constant \& Trend } & t-Statistic & -5.9876 & -6.4503 \\
\hline & Prob. & $0.0000^{* * *}$ & $0.0000^{* * *}$ \\
\hline \multirow[t]{2}{*}{ Without Constant \& Trend } & t-Statistic & -5.8659 & -5.2927 \\
\hline & Prob. & $0.0000^{* * *}$ & $0.0000^{* * *}$ \\
\hline
\end{tabular}

Null hypothesis: the variable has a unit root. Alternative hypothesis: the variable is stationary. (*) Significant at 10\%; (**) Significant at 5\%; (**) Significant at $1 \%$. Lag length based on SIC. $\Delta$ represents the first difference.

Table 2: PP test

\begin{tabular}{|c|c|c|c|}
\hline \multicolumn{4}{|c|}{$\underline{\text { At level }}$} \\
\hline & & UN & REF \\
\hline \multirow[t]{2}{*}{ With Constant } & t-Statistic & -0.9874 & -0.9533 \\
\hline & Prob. & 0.7554 & 0.7672 \\
\hline \multirow[t]{2}{*}{ With Constant \& Trend } & t-Statistic & -2.3881 & -0.6466 \\
\hline & Prob. & 0.3835 & 0.9737 \\
\hline \multirow[t]{2}{*}{ Without Constant \& Trend } & t-Statistic & 1.4685 & 2.0742 \\
\hline & Prob. & 0.9642 & 0.9907 \\
\hline \multicolumn{4}{|c|}{ At first difference } \\
\hline & & $\Delta \mathrm{UN}$ & $\triangle \mathrm{REF}$ \\
\hline \multirow[t]{2}{*}{ With Constant } & $\mathrm{t}$-Statistic & -5.8963 & -6.4170 \\
\hline & Prob. & $0.0000^{* * *}$ & $0.0000^{* * *}$ \\
\hline \multirow[t]{2}{*}{ With Constant \& Trend } & t-Statistic & -5.8690 & -6.4674 \\
\hline & Prob. & $0.0000^{* * *}$ & $0.0000^{* * *}$ \\
\hline \multirow[t]{2}{*}{ Without Constant \& Trend } & t-Statistic & -5.7237 & -5.2648 \\
\hline & Prob. & $0.0000^{* * *}$ & $0.0000^{* * *}$ \\
\hline
\end{tabular}

Null hypothesis: the variable has a unit root. Alternative hypothesis: the variable is stationary. (*) Significant at 10\%; (**) Significant at 5\%; (***) Significant at $1 \%$. Lag length based on SIC. $\Delta$ represents the first difference. 


\section{Engle and Granger residual-based co-integration test}

The result of Engle and Granger co-integration test are given in Table 3.11 We test the null hypothesis of no co-integration in the series. We reject the null hypothesis at $5 \%$ significance level since p-value is less than $5 \%$. So, the results of Engle and Granger co-integration test indicates a long-run co-integration relationship between UN and REF series.

Table 3. Engle and Granger test

\begin{tabular}{|l|c|c|}
\hline Dependent & z-statistic & Prob. \\
\hline UN & -63.50807 & 0.0351 \\
\hline
\end{tabular}

\section{Johansen co-integration test}

Johansen $(1988,1991)$ maximum eigenvalue and trace test results are shown in Table 4. Based on the results given in Table 4, both trace test and max-eigenvalue test indicates that there is one co-integrating equation at the $5 \%$ significance level.12

Table 4. Johansen test

\begin{tabular}{|l|c|c|c|c|}
\hline \multicolumn{4}{|l|}{ Unrestricted co-integration rank test (Trace) } & \\
\hline Hypothesized & & Trace & $5 \%$ & \\
\hline No. of CE(s) & Eigenvalue & Statistic & Critical Value & Prob. \\
\hline None * & 0.254 & 31.002 & $25.872^{*}$ & 0.010 \\
\hline At most 1 & 0.060 & 5.4394 & 12.517 & 0.534 \\
\hline$*$ denotes rejection of the hypothesis at the 5\% significance level \\
\hline
\end{tabular}

\begin{tabular}{|l|c|c|c|c|}
\hline Unrestricted co-integration rank test (Maximum-Eigenvalue) \\
\hline Hypothesized & & Max-Eigenvalue & $5 \%$ & \\
\hline No. of CE(s) & Eigenvalue & Statistic & Critical Value & Prob. \\
\hline None ${ }^{*}$ & 0.254 & 25.562 & $19.387^{*}$ & 0.005 \\
\hline At most 1 & 0.060 & 5.4394 & 12.518 & 0.534 \\
\hline$*$ denotes rejection of the hypothesis at the 5\% significance level \\
\hline
\end{tabular}

\section{Toda and Yamamoto test for causality}

Here we apply Toda and Yamamoto (1995) (TY henceforth) causality test to determine the direction of causality between our variables. TY test is similar to Granger-causality tets but is appropriate for our data since our variables are both non-stationary I(1), in which case the standard Granger causality

11 Dependent variable is UN and REF is the explanatory variable. The first regression is run with a constant and trend specification and monthly dummies.

12 The test is applied with monthly dummies and a linear trend with 12 lags included. 
test and the inference with the corresponding Wald statistic become invalid (Engle and Granger, 1987). For the TY test, we run a VAR(p) model to our variables 13 in levels, and then intentionally over-fit the model with an additional 1 lag. Then we make use of the 'modified' Wald statistic, which has a chi-square distribution asymptotically. ${ }^{14}$ Table 5 presents the $p$-values of the modified Wald statistic. The null hypothesis is no causality running from the explanatory variable to the dependent variable. If dependent variable is UN, we reject the null hypothesis of no causality from REF variable to UN at $10 \%$ significance level (in fact we almost about to reject it at 5\% significance level). If dependent variable is REF, we do not reject the null hypothesis of no causality from UN variable to REF at 10\%, 5\% and 1\% significance levels.

We conclude that the causality only runs from REF to UN, which means that $\mathrm{REF}$ is weakly exogenous in the bivariate system. The test result reveals there is a unidirectional causal relation. Syrian refugees Granger causes unemployment series in Turkey but not vice versa. In our co-integration setting this implies that UN is the only variable that makes all the adjustment in the shortrun whenever there is a deviation from the long-run path. 15

Table 5. TY test

Dependent variable: UN

\begin{tabular}{llll}
\hline \hline Excluded & Chi-sq & df & Prob. \\
\hline \hline REF & 20.51373 & 12 & 0.0580 \\
\hline \hline Dependent variable: REF & & \\
\hline \hline Excluded & Chi-sq & df & Prob. \\
\hline \hline UN & 9.867641 & 12 & 0.6276 \\
\hline \hline
\end{tabular}

\section{Vector Error Correction Representation and Tests of Weak Exogeneity}

As a second approach, we test the weak exogeneity of REF through a VECM model. Since our variables are co-integrated CI(1,1), we can form an error correction model (vectoral form) to test for weak exogeneity of any of our variables.

$\Delta(U N)_{t}=a_{1}+\sum_{i=1}^{p} a_{2 i} \Delta(U N)_{t-i}+\sum_{i=1}^{p} a_{3 i} \Delta(R E F)_{t-i}+\alpha_{U}\left(U N_{t-1}-\beta R E F_{t-1}\right)+\mu_{1 t}$

$\Delta(R E F)_{t}=b_{1}+\sum_{i=1}^{p} b_{3 i} \Delta(U N)_{t-i}+\sum_{i=1}^{p} b_{2 i} \Delta(R E F)_{t-i}+\alpha_{R}\left(U N_{t-1}-\beta R E F_{t-1}\right)+\mu_{2 t}$ (10)

13 We set $\mathrm{p}=12$ because we have monthly data, and also we observe that the correlogram structure behaves best when lag is specified to be 12 .

14 For more details on TY procedure Dave Giles' website is an excellent source: https:// davegiles.blogspot.com/2011/04/testing-for-granger-causality.html.

15 Weak exogeneity is tested through Granger-causality tests in a co-integration setting (Enders, 2015: p. 358-359). 
In equations 9 and 10, the parameters $\alpha_{U}$ and $\alpha_{R}$ represent the error correction parameters and UN and REF variables are co-integrated with the co-integrating vector $(1,-\beta)$. If there is any deviation from the long-run relationship or the co-integrating equation $\left(\mathrm{UN}_{\mathrm{t}-1}-\beta \mathrm{REF}_{\mathrm{t}-1}\right)$ either $\mathrm{UN}$ or REF or both should make the necessary adjustments to attain that equilibrium. If any of the error correction parameters $\left(\alpha_{U}\right.$ or $\alpha_{R}$ in our case) is zero then it means the corresponding variable of that parameter does not adjust to any deviation and that variable is weakly exogenous in the system. Through a VECM estimation, we can test whether $\alpha_{U}$ or $\alpha_{R}$ is equal to zero. ${ }^{16}$ Table 6 displays the results of VECM parameter estimates of error correction coefficients and respective t-statistics. ${ }^{17}$

Table 6. VECM estimation

\begin{tabular}{llc} 
Dependent Variable: & $\Delta(\mathrm{UN})$ & $\Delta(\mathrm{REF})$ \\
\hline \hline Error Correction Parameter & -0.292809 & 0.005535 \\
Standard Error & $(0.06538)$ & $(0.07641)$ \\
t-statistic & {$[-4.47840]$} & {$[0.07243]$}
\end{tabular}

From Table 6, $\alpha_{U}$ is found to be significantly different from zero, at the same time we cannot reject the null that $\alpha_{R}$ is zero. Thus UN is the only series in our system that makes all the adjustments for the long-run equilibrium and REF is weakly exogenous.

\section{ARDL model}

We estimate an ARDL model to obtain the long-term and short-term coefficients simultaneously. 18 In Table 7, the results of the bounds test are illustrated. Computed F-statistics is 7.43 which is higher than the upper bound critical value at $1 \%$ significance level (6.73). We reject the null hypothesis of no long-run relationship at 1\% significance level and accept the alternative hypothesis that there exists one. Since the critical values simulated in Pesaran et al. (2001) require a large sample size, we also apply the test with the critical values obtained by Narayan (2005). Table 8 displays the results. According to Table 8, we confirm the existence of a long-run relationship between UN and REF at $1 \%$ significance level. This finding is consistent with our co-integration results found through Johansen and Engle and Granger tests previously.

The usage of a single-equation ARDL model such as ours is suggested when there exists a single unique co-integrating vector among the variables of

16 Note that both $\alpha_{U}$ and $\alpha_{R}$ cannot be equal to zero at the same time due to existence of cointegration. We can make use of a standard t-test here for significance of the estimated coefficients as the dependent variables (first differences) and the co-integrating equation $\left(\mathrm{UN}_{\mathrm{t}-1}-\beta \mathrm{REF}_{\mathrm{t}-1}\right)$ are stationary.

17 We include a linear time trend and monthly dummies in our estimations.

18 ARDL $(12,10)$ is chosen among 156 models with ordinary standard errors and covariance. We include monthly dummies and trend. 
interest and when all the right-hand-side variables are weakly exogenous (Harris and Sollis, 2003: p. 18).

Table 7. ARDL bounds test Dependent Variable: $\Delta \mathrm{UN}$

\begin{tabular}{|l|c|c|c|c|}
\hline & Value & Signif. & I(0) & I(1) \\
\hline F-statistic & 7.43 & $10 \%$ & 4.05 & 4.49 \\
\hline $\mathrm{K}$ & 1 & $5 \%$ & 4.68 & 5.15 \\
\hline & & $2.5 \%$ & 5.30 & 5.83 \\
\hline & & $1 \%$ & 6.10 & 6.73 \\
\hline
\end{tabular}

Null Hypothesis: No levels relationship. Lower critical values $I(0)$ and higher critical values I(1) for F-test are simulated by Pesaran et al. (2001) (T=1,000, see p. 301).

Table 8. ARDL bounds test with Narayan (2005) critical values. Dependent Variable: $\Delta U N$

\begin{tabular}{|l|c|c|c|c|}
\hline & Value & Signif. & I(0) & I(1) \\
\hline F-statistic & 7.43 & $10 \%$ & 3.11 & 3.61 \\
\hline $\mathrm{K}$ & 1 & $5 \%$ & 3.74 & 4.30 \\
\hline & & $1 \%$ & 5.15 & 5.91 \\
\hline
\end{tabular}

Null Hypothesis: No levels relationship. Lower critical values $I(0)$ and higher critical values I(1) for F-test are simulated by Narayan (2005) (T=80 see p. 1989).

In Table 9, the long-run coefficients of ARDL model are provided (coefficients $\mathrm{e}_{4}$ and $\mathrm{e}_{5}$ ). The long-run coefficient of unemployment itself is -0.284 and that of Syrian refugees is -0.038 . This shows that the effect of REF on UN in Turkey is negative in the long-run but has a smaller contribution in comparison to UN data itself. 19

19 Although not reported here, short-term coefficient of REF on UN is also negative, estimated to be -0.118 . The estimated coefficient, however, cannot be tested for significance through conventional t-tests because REF is an I(1) variable and this is after all an OLS regression. Conventional $t$ and $F$ tests apply only to stationary variables (Enders, 2015: p. 217). The results of all ARDL estimations are available from the authors upon request. 
Table 9. ARDL long-run coefficients Dependent Variable: $\Delta \mathrm{UN}$

\begin{tabular}{|l|l|c|c|c|}
\hline Regresssor & & Coefficient & Std. Error & t-Statistic \\
\hline UNt $(-1)$ & & -0.284 & 0.058 & -4.810 \\
\hline REFt(-1) & & -0.038 & 0.082 & -0.462 \\
\hline
\end{tabular}

The error correction term (ECT) is -0.284 . This is the speed of adjustment parameter for the deviations from long-run path. ECT is expected to be negative and statistically significant in ARDL model estimations. ${ }^{20}$ ECT shows that $28.4 \%$ of the last month's disequilibrium in unemployment from its long-run path will be adjusted in the current month, which indicates a rather unquick adjustment.

Table 10. ARDL model diagnostics

\begin{tabular}{|l|c|c|c|}
\hline Item & Test Applied & Chi-Square & Prob. \\
\hline Serial Correlation & Breusch-Godfrey LM test & 1.56 & 0.14 \\
\hline Normality & Jarque-Bera (JB) statistic & 2.60 & 0.27 \\
\hline Heteroscedasticity & Breusch-Pagan-Godfrey & 0.75 & 0.80 \\
\hline
\end{tabular}

As can be seen in Table 10, the model does not suffer from the problem of serial correlation, normality or heteroscedasticity. The stability of ARDL model is checked via the graphical representations of the cumulative sum of recursive residuals (CUSUM) test and cumulative sum of squares of recursive residuals (CUSUMSQ) test. Both of CUSUM and CUSUMSQ are within the critical bounds of $5 \%$. It reveals that the model is structurally stable and there is no problem of occurrence of structural breaks.

20 The reported t-statistic's (-4.81) asymptotic distribution is no longer the conventional $\mathrm{t}$-distribution. Significance of this t-statistic can be tested through the critical values displayed in Pesaran et al. (2001) for $\mathrm{T}=1000$. At 1\% significance level, we observe significance of the t-statistic (Pesaran et al. 2001, p. 304). The significance of this statistic can also be tested by the method proposed in Ericsson and MacKinnon (2002) for a smaller sample size $\mathrm{T}=100$. The critical value at $1 \%$ significance level is -4.35 which makes our reported t-statistic significant. This result is consistent with our conclusion that there is a long-run relationship between UN and REF series at 1\% significance level. Similarly, t-statistic reported on REF(1) in Table 9, does not follow the conventional t-distribution asymptotically because REF is an I(1) variable (Enders, 2015: p. 217). We make use of FM-OLS, DOLS and CCR models to estimate the direct effects of REF on UN in the long-run and analyze coefficient signs and significance tests. 
Figure 7. Plot of cumulative sum of recursive residuals

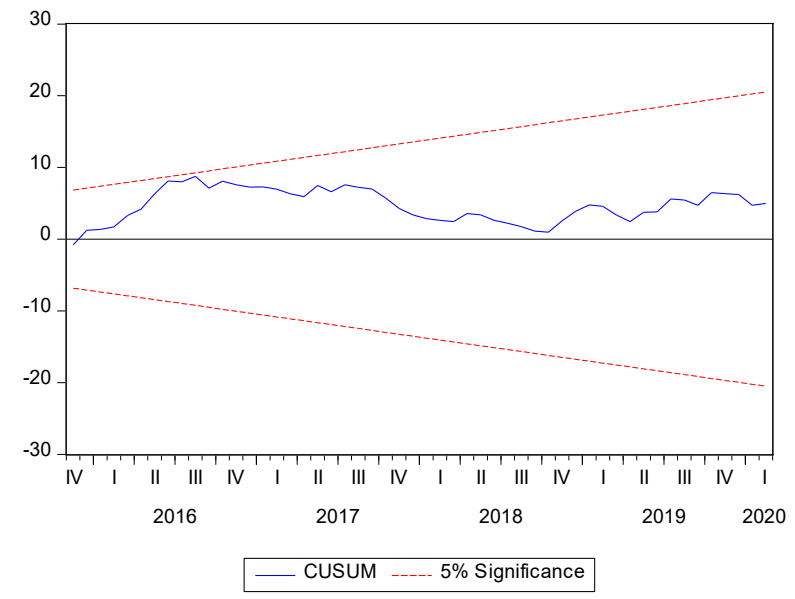

Figure 8. Plot of cumulative sum of squares of recursive residuals

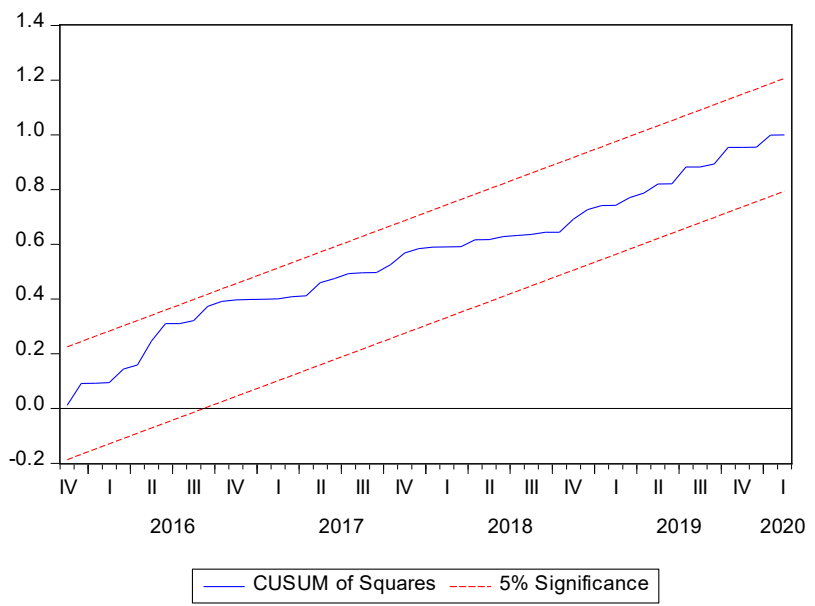

\section{FM-OLS, DOLS and CCR estimations}

In this section, we apply fully modified least squares (FM-OLS), dynamic OLS (DOLS), and canonical co-integrating regression (CCR) methods. ${ }^{21}$ Tables 11 , 12 , and 13 report the coefficients which denote the effects of REF on UN. The coefficients estimated to be $-0.26,-0.313$, and -0.26 respectively for FM-OLS, DOLS and CCR. The coefficients are negative and significant at 5\% significance level (CCR's coefficient is significant at 10\%). setting. FM-OLS, DOLS and CCR procedures have advantages over OLS. FM-OLS and DOLS have been shown to provide robust results in small samples (Narayan, 2005). 
Table 11: FM-OLS estimation results

Dependent Var: UN

\begin{tabular}{lllll} 
Variable & Coefficient & Std. Error & t-Statistic & Prob. \\
\hline \hline REF & -0.260784 & 0.136208 & -1.914592 & 0.0585 \\
\hline \hline R-squared & 0.898228 & Adj. R-squared & 0.896107
\end{tabular}

Table 12: DOLS estimation results

Dependent Var: UN

\begin{tabular}{lllll} 
Variable & Coefficient & Std. Error & t-Statistic & Prob. \\
\hline \hline REF & -0.313000 & 0.150875 & -2.074562 & 0.0409 \\
\hline \hline R-squared & 0.898758 & Adj. R-squared & 0.893195
\end{tabular}

Table 13: CCR estimation results

Dependent Var: UN

\begin{tabular}{lllll} 
Variable & Coefficient & Std. Error & t-Statistic & Prob. \\
\hline \hline REF & -0.261222 & 0.139327 & -1.874889 & 0.0638 \\
\hline \hline R-squared & 0.898227 & Adj. R-squared & 0.896107 \\
\hline
\end{tabular}

Our findings from FM-OLS, DOLS and CCR regression estimations of UN on REF show that arrival of every 10 Syrians drops the number of unemployed in Turkey approximately by 3. This finding relates to the findings of Aksu et al. (2018); they show migrant shock has a substantial positive effect on men's employment in the 'formal' labor market. ${ }^{22}$ They find that the arrival of every 10 Syrians generates about 5.5 jobs for native men: roughly 3 jobs are for wage workers, 1.7 jobs for the self-employed, 0.54 jobs for employers and 0.35 jobs for unpaid family workers.

\section{Conclusion}

We empirically analyze the impact of Syrian refugees on the number of unemployed persons in Turkey. We follow a time series approach with monthly official data on Turkish unemployment, and the number of Syrian refugee series in Turkey between 2011:11 and 2020:2. We make use of different econometric techniques with underlying asymptotic theories appropriate for the type of variables we work with. After showing that our variables are both I(1), we confirm that our variables are co-integrated that they share common

22 Workers in the formal sector are the ones who have social security coverage. 
stochastic trends. Statistical inferences are drawn from ARDL, FM-OLS, DOLS, and CCR methods.

Empirical results show that there is a significant negative relationship between the number of Syrian refugees and the unemployment numbers in Turkey. In a co-integration setting, we find that Turkish unemployment data does all the adjustment reverting back to the long-run equilibrium. The speed of convergence is such that; $28.4 \%$ of the last month's disequilibrium will be adjusted in the current month. We estimate that the arrival of every 10 Syrians drops the number of unemployed persons in Turkey approximately by 3 . This empirical finding of a negative relationship between unemployment and refugee data may be explained on different grounds.

In the section where we examine the theoretical implications of Borjas (2013), it is mentioned that, in case when the immigrants are complementary to the native labor force, refugees can fill up important niches and make native workers shift to more productive jobs. In fact, it is known that immigrant workers tend to accept 3D (dirty, dangerous and demeaning) jobs way more easily then the natives. Thus immigrant workers complementing the native workforce has the ability to shift the local workers to more complex jobs filling up the 3D ones.

Since Syrian refugees did not have legal work permits until 2016, their employment in the formal sector was restricted. As reported by Kirişçi (2014), they competed with local workers on the informal, low-wage and labor-intensive jobs in industries like construction, textile, manufacturing, heavy-industry, and agriculture. This competition still exists in labor-intensive sectors. These are low-paying jobs which Turkish workers are unwilling to accept easily. ${ }^{23}$ As Akgündüz and Torun (2019) points out, Syrian refugees are, complements in the labor market complements in the labor market for complex tasks.

Syrian migration can also boost regional demand, capital supply in Turkey (Cengiz and Tekgüç, 2018). Given a large influx of Syrian refugees, Turkish economy is experiencing an excess demand on goods market which immediately increases the labor demand. Akgündüz et al (2015) study reveals that Syrian refugees lead to an increase in the food and housing prices Also, many Syrians invested in Turkey by setting up their own firms: bakeries, businesses, travel agencies and restaurants...etc. (Kirişçi, 2014). Some Syrians moved their firms to Turkey (contributing to the capital stock) and even exported their products abroad.

Turkish government's increased spending and European Union's, together with international agencies' humanitarian aids have a possible boosting

23 Syrians filling this gap and working for long hours at lower wages will lower the production costs. In addition, social security premiums and taxes are not possibly being paid for many unregistered Syrians. 
effect on the economy as well. Turkey spent $\$ 40$ billion (Yarar, 2019); EU spent $€ 10.9$ billion as humanitarian funding and aid since 2011 (European Union, 2019) for refugees in Turkey (also see Aygün (2020).

All the impacts mentioned above: complementary behavior of Syrian labor force to the existing Turkish labor force, humanitarian aids, capital flows done by Syrians into Turkey, and growing demand in goods market can alter the composition of labor market in Turkey and lead to creation of jobs increasing the economic activity eventually (Del Carpio and Wagner, 2015). These impacts have possibly influenced the unemployment.24

\section{References}

Akgündüz, Y. E., \& Torun, H. (2019). Two and a Half Million Syrian Refugees, Tasks and Capital Intensity. Central Bank of the Republic of Turkey Working Paper No: 19/23.

Akgündüz, Y. E., Berg, M., \& Hassink, W. (2015). The Impact of Refugee Crises on Host Labor Markets: The Case of the Syrian Refugee Crisis. Disscussion Paper, no.8841; onn: IZA. IZA Disscussion Paper, no.8841.

Aksu, E., Erzan, R., \& Kırdar, M. G. (2018). The Impact of Mass Migration of Syrians on the Turkish Labor Market. Bonn: IZA Discussion Papers The IZA Institute of Labor Economics.

Al-Azzam, A., \& Hawdon, D. (1999). Estimating the Demand for Energy: A Stock and Watson Dynamic OLS (DOLS) approach. Surrey Energy Economics Discussion Paper series.

Ali, F., \& Ibrahim, M. (2016). The Impact of Syrian Refugees on the Labor Market in Neighboring Countries: Empirical Evidence from Jordan. Defence and Peace Economics, 27(1), 64-86.

Aygün, E. (2020). European Civil Protectionand Humanitarianaid Operations. https:// ec.europa.eu/echo/where/europe/turkey_en

Bahçekapıl1, C., \& Çetin, B. (2015). The Impacts of Forced Migration on Regional Economies: The Case of Syrian Refugees in Turkey. International Business Research Vol: 8 No:9, 1-15.

Borjas, G. J. (2013). Labor Economics. New York: McGraw-Hill.

Boubtane, E., Coulibaly, D., \& Rault, C. (2013). Immigration, Growth, and Unemployment: Panel VAR Evidence from OECD Countries. TOC Volume 27 Issue 4, 399-420.

Card, D. (1990). The Impact of the Mariel Boatlift on the Miami Labor Market. Industrial and Labor Relations Review 43, 245-257.

24 One should also consider the 'discouraged worker effect' however. Native workers who observe that finding a job is difficult for a long period might give up looking for a job thus drop out of the labor force, reducing unemployment numbers. 
Cengiz, D., \& Tekgüç, H. (2018). Is It Merely a Labor Supply Shock? Impacts of Syrian Migrants on Local Economies in Turkey. Universitiy of Massachusetts Amherst Political Economy Research Institute Working Paper Series No: 454.

Ceritoglu, E., Yunculer, B. G., Torun, H., \& S., T. (2017). The Impact of Syrian Refugees on Natives' Labor Market Outcomes in Turkey: Evidence from a Quasi-experimental Design. IZA J Labor Policy 6, 5, https://doi.org/10.1186/s40173-017-0082-4.

Çakılc1, E. (2017). Do Syrian Refugees Have a Real Impact on Local Unemployment in Turkey? Journal of Human Sciences, 14(2), 1207-1214.

Damette, O., \& Fromentine, V. (2013). Migration and Labour Markets in OECD Countries: A Panel Co-integration Approach. Applied Economics, 45 (16), 2295-2304.

David, A., A., M. M., C., N., \& B., N. (2020). The Economics of the Syrian Refugee Crisis in Neighbouring Countries: The Case of Lebanon. Economics of Transition and Institutional Change Vol. 28 (1), 89-109.

Del Carpio, X. V., \& Wagner, M. C. (2015). The Impact of Syrian Refugees on the Turkish Labor Market : The impact of Syrians refugees on the Turkish labor market. Policy Research Working Paper; No: WPS 7402.

Dickey, D., \& Fuller, W. (1979). Distribution of the Estimators for Autoregressive Time Series with a Unit Root. Journal of the American Statistical Association, 74, 427-431.

Dickey, D., \& Fuller, W. (1981). Likelihood Ratio Statistics for Autoregressive Time Series with a Unit Root. Econometrica, 49, 1057-1072.

Docquier, F., Özden, Ç., \& Peri, G. (2011). The Labor Market Effects of Immigration and Emigration in OECD Countries. IZA Discussion Papers No. 6258.

Dumont, J.-C., \& Liebig, T. (2014, 5 1). OECD Migration Policy Debates: Is migration good for the economy? Paris: OECD, International Migration Division.

Dustmann, C., Fabbri, F., \& Preston, I. (2005). The Impact of Immigration on the British Labour Market. The Economic Journal, 115, 324-341.

Enders, W. (2015). Applied Econometric Time Series 4th ed. NewYork: Wiley.

Engin, C., \&Konuk, T. (2020). Türkiye Ekonomisinde Uluslararası Göçün İşsizlikve Ekonomik Büyüme Üzerine Etkisi: Ekonometrikbir Analiz. Kahramanmaraş Sütçü İmam Üniversitesi İktisadi ve İdari Bilimler Fakültesi Dergisi, 10(1),103-123.

Engle, R., \& Granger, G. (1987). Co-integration and Error Correction: Representation, Estimation and Testing. Econometrica, 55, 51-276.

Ericsson, N., \& MacKinnon, J. G. (2002). Distributions of Error Correction Tests for Co-integration. Econometrics Journal, 5, 285-318.

Esen, O., \& Oğuş Binatlı, A. (2017). The Impact of Syrian Refugees on the Turkish Economy: Regional Labour Market Effects. Social Sciences, 6, 129.

European Union. (2020). The EU Response to the Refugee Crisis in Turkey. Retrieved from Delegation of the European Union to Turkey: https://www.avrupa.info.tr/en/eu-response-refugee-crisis-turkey-710. 
Fallah, B., Krafft, C., \& Wahba, J. (2019). The impact of refugees on employment and wages in Jordan. Journal of Development Economics, 139, 203-216.

Feridun, M. (2007). Immigration, Income and Unemployment: An Application of the bounds testing Approach to Cointegration. The Journal of Developing Areas. 41(1), pp. 3749.

Giles, D. (2011). Testing for Granger Causality. https://davegiles.blogspot.com/2011/04/ testing-for-granger-causality.html

Haug, A. A. (2000). Temporal Aggregation and the Power of Cointegration Tests: A Monte Carlo Study. Oxford Bulletin of Economics and Statistics, 64, 399-412.

Harris, J. A. (1970). Migration, Unemployment and Development: A Two-sector Analysis. American Economic Review, 60, 126-142.

Harris, R., \& Sollis R.. 2003. Applied Time Series Modelling and Forecasting. West Sussex: Wiley

Hercowitz, Z. A. (1999). A Macroeconomic Experiment in Mass Immigration. CEPR Discussion Papers 2983, C.E.P.R. Discussion Papers.

Hunt, J. (1992). The Impact of the 1962 Repatriates from Algeria on the French labor market. Industrial and Labor Relations Review, 45(3), 556-572.

Jean S., J. M. (2007). The Unemployment Impact of Immigration in OECD Countries. OECD Economics Department Working Paper, No. 563.

Johansen, S. (1988). Statistical Analysis of Co-integration Vectors. Journal of Economic Dynamics and Control, 12 (2-3), 231-254.

Johansen, S. (1991). Estimation and Hypothesis Testing of Co-integration Vectors in Gaussian Vector. Econometrica, 59(6), 1551-1580.

Kirişçi, K. (2014). Syrian Refugees and Turkey's Challenges: Going beyond Hospitality. Washington, D.C.: The Brookings Institution.

Lee, J., \& Strazicich, M. C. (2003). Minimum Lagrange multiplier unit root test with two structural breaks. Review of Economics and Statistics, 85, 1082-9.

Meçik, O., \& Koyuncu, T. (2020). Türkiye'de Göç ve Ekonomik Büyüme İlişkisi: TodaYamamoto Nedensellik Testi. Journal of the Human and Social Science Researches, 9(3), 2618-2635.

Narayan, P. K. (2005). The Saving and Investment Nexus for China: Evidence from Co-integration Tests. Applied Economics, 37, 1979-1990.

Narayan, P. K., \& Narayan, S. (2005). Estimating income and price elasticities of imports for Fiji in a co-integration framework. Economic Modelling, 22, 423- 438.

Ng S., \& Perron, P. (2001). Lag length selection and the construction of unit root tests with good size and power. Econometrica, 69, 1519-1554.

Orhan, O. \& Gündoğar S., S. (2015). Effects of the Syrian Refugees on Turkey. Ankara: ORSAM Report No: 195. 
Park, J. (1992). Canonical Co-integrating Regressions. Econometrica: Journal of the Econometric Society, Vol.60(1), 119-143.

Pesaran, M. H., \& Shin, Y. (1999). An Autoregressive Distributed Lag Modelling Approach to Cointegration Analysis. In S. Strom (Ed.), Econometrics and Economic Theory in the 20th century: The Ragnar Frish Centennial Symposium (pp. 371-413). Cambridge University Press.

Pesaran, M. H., Shin, Y., \& Smith, R. J. (2001). Bounds Testing Approaches to the Analysis of Level Relationships. Journal of Applied Econometrics, 16(3), 289-326.

Phillips, P., \& Hansen, B. (1990). Statistical İnference in İnstrumental Variables Regression with I(1) Processes. The Review of Economic Studies, 57(1), 99-125.

Phillips, P., \& Perron, P. (1988). Testing for a Unit Root in Time Series Regression. Bimetrika, 75, 335-346.

Pischke, J., \& Velling, J. (1997). Employment Effects of Immigration to Germany: An Analysis based on Local Labor Markets. Review of Economics and Statistics 79(4), 594-604.

Raphael, S., \& Ronconi, L. (2007). The Effects of Labor Market Competition with Immigrants on the Wages and Employment of Natives: What Does Existing Research Tell Us? Du Bois Review: Social Science Research on Race, Volume 4, Issue 2.

Sims, C. A. (1980). Macroeconomics and Reality. Econometrica, 48(1), 1-48.

Stock, J., \& Watson, M. (1993). A Simple Estimator of Co-integrating Vectors in Higher Order Integrated Systems. Econometrica: Journal of the Econometric Society, 61(4), 783-820.

Suzuki, K., Paul, S., Maru, T., \& Kusadokoro, M. (2019). An Empirical Analysis of the Effects of Syrian Refugees on the Turkish Labor Market. ADBI Working Paper 935.

TCMB. (2020). Basic Labour Force Indicators (TURKSTAT)(15+age). Central Bank of Turkey: https://evds2.tcmb.gov.tr/index.php?/evds/searchEvdsValue/QGnFn3NpekA= on 05.06.2020

Toda, H.Y. \& Yamamoto, M. (1995). Statistical Inferences in Vector Autoregressions with Possibly Integrated Processes. Journal of Econometrics, 66(1-2), 225-250.

Tumen, S. (2016). The Economic Impact of Syrian Refugees on Host Countries: Quasi-experimental Evidence from Turkey. American Economic Review, 106 (5), 456-60.

UNHCR. (2020). Registered Syrian Refugees by Date. Syria Regional Refugee Response - Inter agency Information sharing portal: http://data.unhcr.org/syrianrefugees/country. php?id=224.

Yarar, E. (2019). Turkey alone in its diplomatic, humanitarian efforts to assist Syrian refugees. Daily Sabah: https:/www.dailysabah.com/diplomacy/2019/12/31/turkey-alone-in-its-diplomatic-humanitarian-efforts-to-assist-syrian-refugees on 28.05.2020. 